\title{
ジオシンセティックスを用いた落石防護擁壁の実験的研究
}

\author{
(株)エイ・シイ・デイ 㴊上正浩・小畑康隆 福井大学工学部 荒井克彦・小嶋啓介 \\ (株)プロテックエンジニアリング 井上昭一 前田工織(株) 久保哲也
}

著者らは，ジオシンセティックスを用いた補強土擁壁による落石防護擁壁として，土堤型の落石防 護補強土擁壁の開発を行ってきたが，土堤型の場合，設置する際に道路際にある程度の平場が必要と なり，地形によっては設置が困難となる，そこで，道路際の平場が小さい地形に対応した落石防護補 強土擁壁として，地山に治った補強盛土の天端で落石を受け止める，ポケット式落石防境補強土甡壁 の開発を行った。本稿は, ポケット式落石防護補強土㩳壁の, 落石衝突時の衝撃力吸収性能の確認を 目的とした、重錘落下実験の報告である.

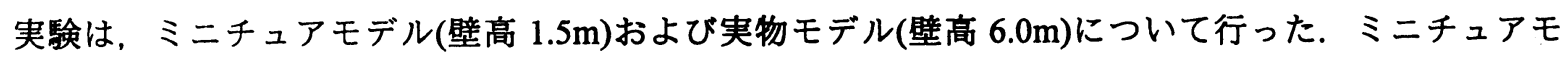
デルについては，ジオグリッドによる補強を行ったものと補強を行わないものについて実験を行い， 落石衝突時の挙動の違いから補強材の効果の確認を行った。実物モデルについては, 落石衝突時の挙 動および安全性の確認を行った。

キーワード：落石，補強土擁壁，ジオシンセティックス，衝撃実験

\section{Experimental Research of Rainforced Soil Wall for Rock-fall Protecftion}

M.Fuchigami and Y.Obata : ACD,Inc.

K.Arai and K.Kojima : Faculty of Engineering,Fukui University

S.Inoue : ProtecEngineering,Inc.

T.Kubo:MAEDA KOSEN Co.,Ltd.

The retaining reinforced soil wall of Rock-fall protection has been developed for a few years. It need some spaces to construct by it's structure and also there are often few spaces to construct the wall where need to such a protection structure. Therefore the pocket type reinforced soil wall of Rock-fall protection was developed. It can be constructed in narrow space at a roadway side and it can catch a rock by it's top. This paper describes the experimental research of the reinforced soil wall for rock-fall protection. The experiment was performed two models of prototypes, the miniature size model(wall height $1.5 \mathrm{~m}$ ) and actual size model(wall height $6.0 \mathrm{~m}$ ). The experiment of miniature size model was confirmed the effect of geo-grid. And the experiment of actual size model was confirmed behavior the wall when at the moment of collision the rock and it's safety against a huge scale rock fall

Keywords: Rock-fall, Reinforced Soil Wall, Geosynthetics, Impact test 


\section{ジオシンセティックスを用いた落石防護擁壁の実験的研究}

(株)エイ・シイ・デイ 㴊上正浩・小畑康隆 福井大学工学部 荒井克彦・小嶋啓介 (株)プロテックエンジニアリング 井上昭一＼cjkstart前田工縉(株) 久保哲也

1.はじめに

近年，落石対策技術は，研究開発および改良が盛んに行われている，その結果，落石対策に夙する 技術は向上し，落石対策工法も往年に比べると非常に多様化してきている.

落石対策工法のひとつである落石防愎推壁は，現在までコンクリート錐壁が主流であるが，㣚性が 高いことから落石の行突エネルギーの吸収性能が低く，景観および環境に対しても問題があると考え られる.このような状況の中，著者らはこれまで図 1.1 に示すような補強土盛土工法等に用いられて いるジオシンセティックスにより堤防形に築造した「落石防讙補強土啐壁」（以後「堤防型」と称す）

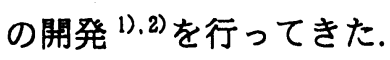

現在，堤防型の落石防護補強土擁壁は，道路際にある程度のスペースを確保できる場合に採用され ている．しかし，落石の発生が予想される路線では道路際で防護施設の設置スペースを確保できない 場合が多い.

そこで，図 1.2 に示すように斜面法尻部に補強土工法により土堤を立ち上げ，道路際に平場を設け ることにより，落石が道路に到達することを防ぐ機能を有した落石防護擁壁を考案した（以後、「ポケ ット式落石防護補強土擁壁」と称す).

本論文では，まずポケット式落石防護補強土擁壁の開発を目的として実施したモデル実験および実 物実験結果について述べる。つぎ，ポケット式落石防護補強土擢壁に作用する衝撃力について考察 し，簡易設計法による照查結果について述べる.

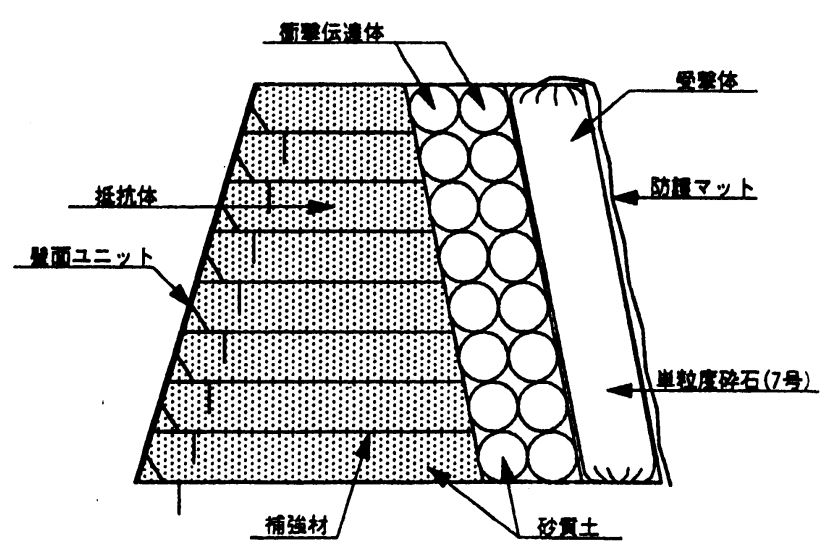

図 1.1 堤防型落石防護補強土㩲壁（従来型）

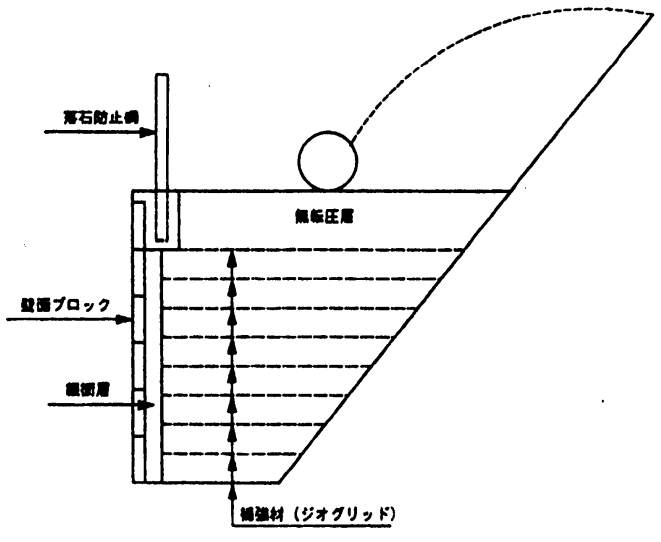

図 1.2 ポケット式落石防護補強土擁壁 
2. モデル実験

\section{1 供試体}

モデル実験は，擁壁上に落石が作用した場合の補強材の効果を確認することを目的に行った。供試 体は，補強材を設置しない Type-1 と補強材を設置するType-2 の 2 種類とし，各 1 体ずつ製作した， 図 2.1 に供試体の形状寸法を示す. 補強材を設置しない Type-1 には，壁面を自立させるために壁面付 近に幅 $300 \mathrm{~mm}$ ，厚さ $2.5 \mathrm{~mm}$ の不織布を，高さ方向に $250 \mathrm{~mm}$ 間隔で設置した．補強材を設置する Type-2 には，引張強度 $32 \mathrm{kN} / \mathrm{m}$ (伸度 5\%) のジオグリッドを高さ方向に $250 \mathrm{~mm}$ 間隔で設置した.

\section{2 実験方法}

実験は，図 2.1 の供試体の中央に重量 $1 \mathrm{kN}(\phi$ $30 \mathrm{~cm}$ )の重錘を高さ $20 \mathrm{~m}$ から落下させた.

測定項目は，重鍾加速度，壁面土圧，壁面変位， 重鍾の貫入量とし，加速度計および荷重計により 測定されたアナログ信号を増幅し， $0.5 \mathrm{msec}$ 間隔 でデジタル量として記録した。荷重計は，壁面材 に作用する衝撃土圧を計測するため，受圧面積が 大きく，両面の圧力を計測できるパネル式土圧計 （福岡式）を試験的に用いた。 また, 高速度カメ ラにより,重鍾の変位を毎秒 200 コマで記録した。 壁面变位は，供試体壁面に反射板を設置し落下 前後の座標を計測し求めた.

\section{3 実験結果}

測定された重錘の加速度に重錘の質量を乗じて 得られた重鍾衝撃力の時間的変化を図 2.2 に示す。

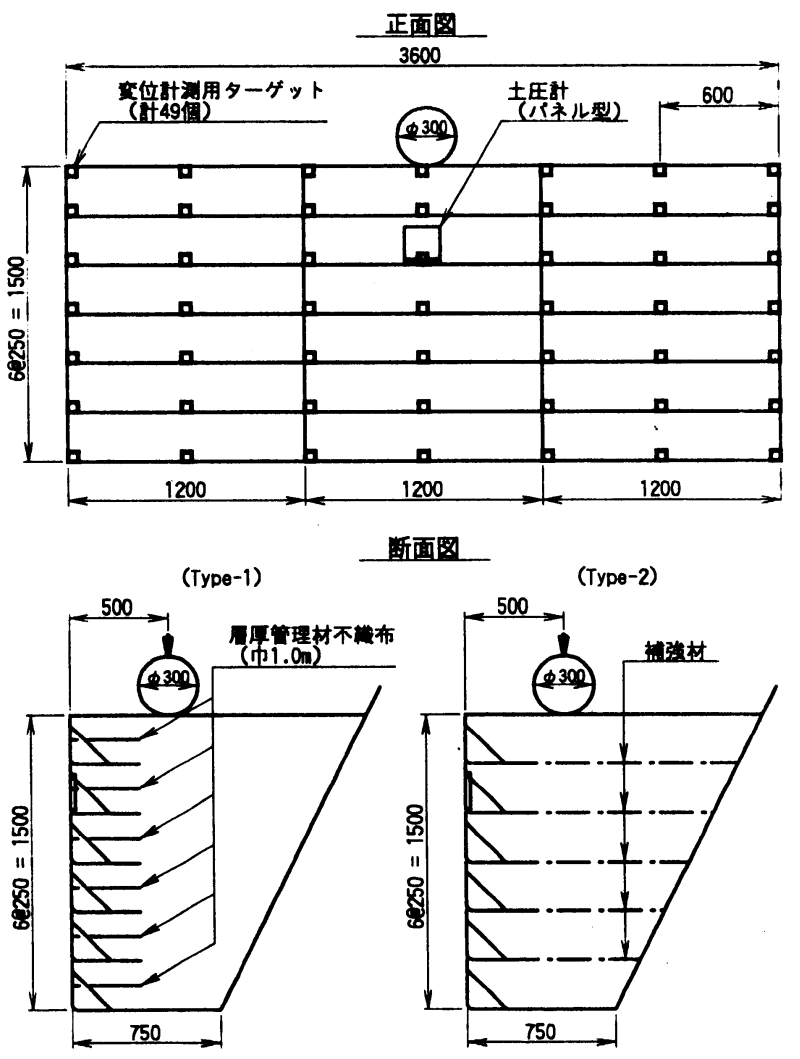

图 2.1 モテル実験供試体形状図

補強材を設置しない Type-1 の重錘衝撃力は $10 \mathrm{msec}$ 程度で最大衝撃力 $52.9 \mathrm{kN}$ を示し，その後 漸減している。

補強材を設置した Type-2 の重䥀衝撃力は $10 \mathrm{msec}$ 程度で最大衝撃力 $60.6 \mathrm{kN}$ を示し，その後 20msec まで漸減し, 30msec までほぼ一定值を保ち 再び漸減している. 20〜30msecにおいて一定値と なったことは，その時の重錘貫入量が $250 \mathrm{~mm}$ 付近 であるため，補強材に接触したことによるものと

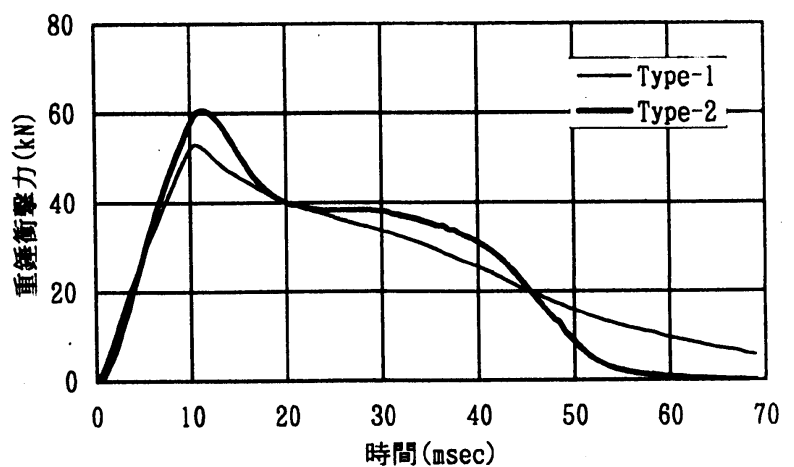

图 2.2 重鍾街费力-時間関係 思われる。 
図 2.3 にパネル式土圧計により計測された壁 面土圧の時間的変化を示す. Type-1 の壁面土圧 は $30 \mathrm{msec}$ 程度で最大值 $36.9 \mathrm{kN} / \mathrm{m}^{2}$ を示し，その 後減少して $60 \mathrm{msec}$ からほぼ一定値となる。 Type-2 の壁面土圧は，20msec 程度で最大值

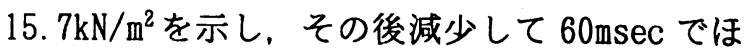
ぼ消滅している. Type-2 の最大土圧は, Type-1 の $1 / 2$ 以下であった.

表 2.1 に供試体壁面の变位量を示す. Type-1 の最大壁面変位は $82 \mathrm{~mm}$ であり, Type-2 の最大壁

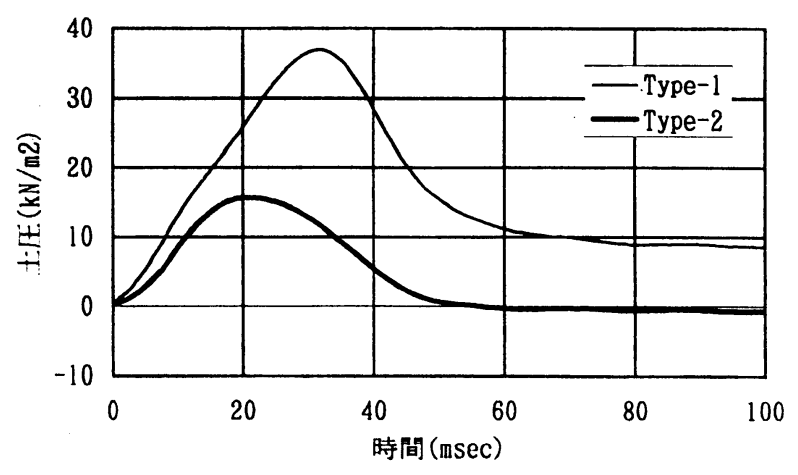

图 2.3 壁面土压-時間関係

表 2.1 壁面变位 面変位は $18 \mathrm{~mm}$ である. Type-2 の壁面 変位はType-1の 1/4 以下の值であった. 貫入量は，Type-1 で 467mm, Type-2で $330 \mathrm{~mm}$ であった。

\section{4 考察}

モデル実験における重錘衝㬝力は， 補強材を設置しない Type-1 に比べて 補強材を設粗した Type-2 の方が大き な值を示した，これは，補強材の配置 により貫入量が抑えられたため大きな 衙慗力が発生したものと思われる，壁 面土圧および壁面変位は Type-2 の方が

\begin{tabular}{|c|c|c|c|c|c|c|c|} 
Type-1 \\
列 & 1 & 2 & 3 & 4 & 5 & 6 & 7 \\
\hline 1 & 0.015 & 0.026 & 0.054 & 0.079 & 0.066 & 0.045 & 0.047 \\
\hline 2 & 0.018 & 0.024 & 0.051 & 0.082 & 0.076 & 0.044 & 0.035 \\
\hline 3 & 0.019 & 0.022 & 0.040 & 0.065 & 0.053 & 0.039 & 0.037 \\
\hline 4 & 0.020 & 0.022 & 0.033 & 0.046 & 0.045 & 0.034 & 0.032 \\
\hline 5 & 0.023 & 0.022 & 0.026 & 0.034 & 0.033 & 0.029 & 0.030 \\
\hline
\end{tabular}

\begin{tabular}{|c|c|c|c|c|c|c|c|}
\hline Type-2 & \multicolumn{1}{|r|}{ (単位: m) } \\
\hline 1 & 1 & 2 & 3 & 4 & 5 & 6 & 7 \\
\hline 2 & 0.011 & 0.010 & 0.009 & 0.007 & 0.006 & 0.007 & 0.007 \\
\hline 3 & 0.013 & 0.009 & 0.016 & 0.018 & 0.008 & 0.006 & 0.006 \\
\hline 4 & 0.011 & 0.009 & 0.011 & 0.015 & 0.006 & 0.006 & 0.005 \\
\hline 5 & 0.012 & 0.008 & 0.011 & 0.0011 & 0.006 & 0.005 & 0.005 \\
\hline
\end{tabular}

小さな值を示した。これは，補強材の設置により壁面土圧が抑えられ，結果として壁面変位が小さく なったものと思われる.

以上のことより，モデル実験では，重錘の鉛直落下に対しては補強材を設置することにより擁壁体 の安定性を高める効果を確認することができた。

\section{3. 実物実験}

\section{1 供試体}

モデル実験により重錘の鉛直落下に対する補強材の補強効果が確認できたことから，図 3.1 に示す 実物大の供試体を製作し，重鍾落下実験を行った。

供試体には補強材として引張強度 $32 \mathrm{kN} / \mathrm{m}$ (伸度 $5 \%$ ) のジオグリッドを高さ方向に $500 \mathrm{~mm}$ 間隔で設置 した．壁面材は壁面ブロックを使用し，背後に厚さ $300 \mathrm{~mm}$ の緩衝層(単粒度砕石)を設けた。 また壁天 端には落石緩衝材として厚さ $1.4 \mathrm{~m}$ の無転圧層を設けた。 


\section{2 实験方法}

実験は, 図 3.1 の供試体の緩衝材中央に, 直 径 $1.54 \mathrm{~m}$, 重量 $51.7 \mathrm{kN}$ の円筒形重錘を, 高さ $20 \mathrm{~m}$ から落下させて行った.

測定項目は, 重鍾加速度, 鉛直土圧, 壁面変 位, 重錘の貫入量とし, モデル実験と同様の方 法により計測を行った．ただし，鉛直土圧は土 中の值を計測するため, 荷重計を $300 \mathrm{~mm} \times 300 \mathrm{~mm}$ の鋼板に固定して埋設した.

\section{3 実験結果}

測定された重錘の加速度に重鍾の質量を乗じ て得られた重鍾衝撃力の時間的変化を図 3.2 に 示す.重鍾衝撃力は $17 \mathrm{msec}$ で最大衝撃力 $2417 \mathrm{kN}$ を示し, その後减少し, $40 \mathrm{msec}$ 程度で消滅して いる。

図 3.3 に荷重計で計測された鉛直土圧の時間 的変化を示す，重鍾落下位置直下に設置した荷 重計 2 の值は $67 \mathrm{msec}$ で最大値 $355.6 \mathrm{kN} / \mathrm{m}^{2}$ を示 し, その後减少して $250 \mathrm{msec}$ 程度で消滅してい る.ここで，この土圧は土砂上に設置された荷 重計の值であり，土砂材の剛性が影響している ため，いわゆる純粋な鉛直土圧ではない，しか しながら, 衝撃力の伝達により内部に発生する 土圧（以後, 衝撃土圧とする）の分散幅につい ては十分確認できるものと思われる.

表 3.1 に壁面ブロックの変位量を示す.

壁面変位は重鍾落下位置の前面で最大変位 97mm を示した．貫入量は，950mm であり，重鍾 は無転圧層内で停止したが，最上段の補強材は 破断した.

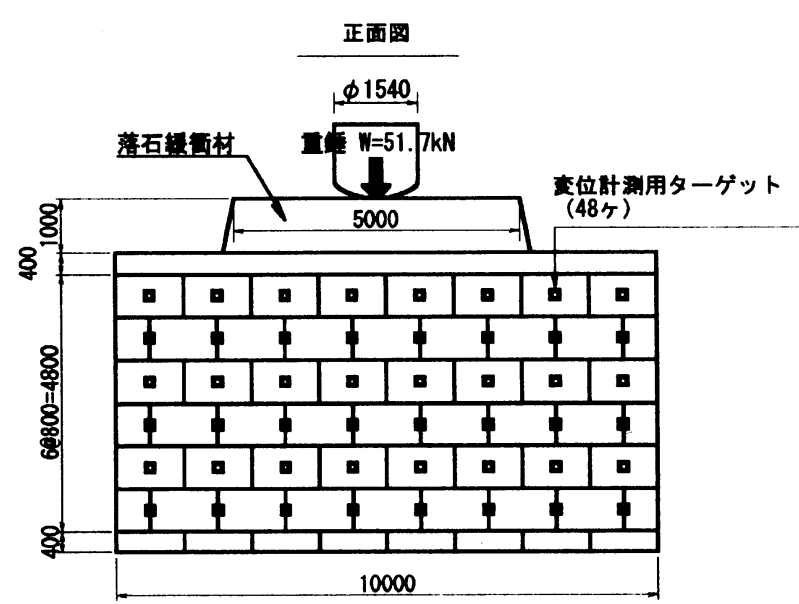

平面图

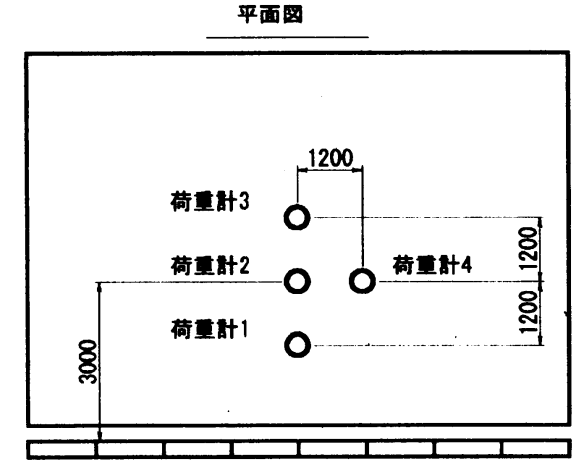

断面图

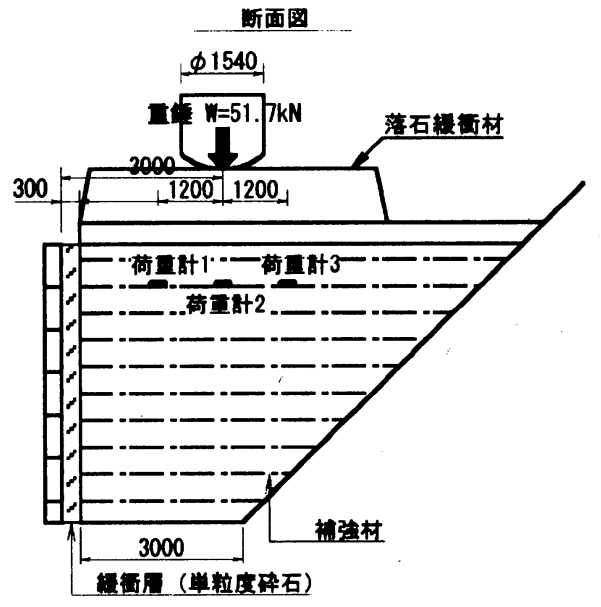

図 3.1 实物实験供試体形状図

\section{4 考察}

実物実験における最大重鍾衝撃力は，2417kN であった。この值から，式(3.1)に示す，振動便覧にお ける落石衝撃力の推定式を用いて被衝突体の剛性を表すラーメ定数を算出した結果, 約 $700 \mathrm{kN} / \mathrm{m}^{2}$ であ った。 


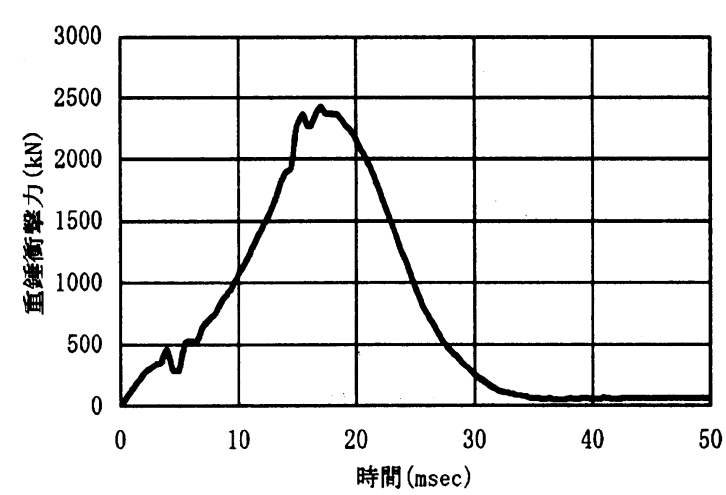

图 3.2 亘鍾语繁力-時間関係

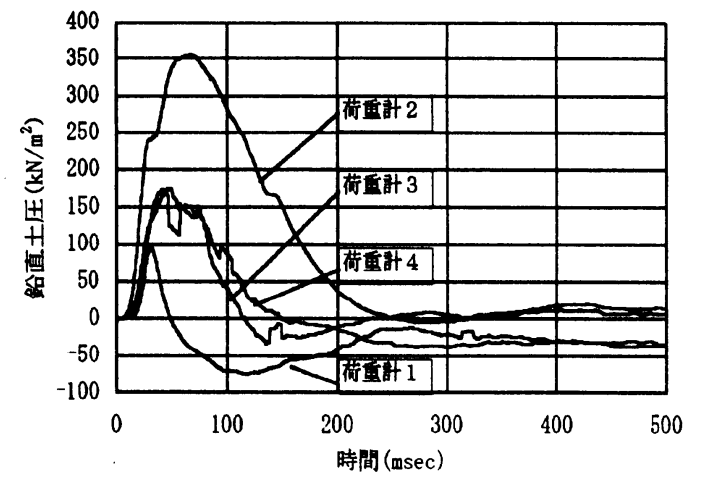

図 3.3 鉛直土圧一時間関係

ロックシェッド等の設計に用いられる緩衝 材のラーメ定数は一般的に $1000 \mathrm{kN} / \mathrm{m}^{2}$ 程度で あるとされており，本実験において計測され た衝擊力は概ね妥当な值であると思われる. また，振動便筧における落石衝撃力の推定式 に対応した重錘の貫入量は式(3.2)で表 される ${ }^{3)}$.

$$
\begin{aligned}
& P=2.455 W^{2 / 3} \cdot \lambda^{2 / 5} \cdot H^{3 / 5} \\
& y=\left(\frac{45 W H}{64 \lambda}\right)^{2 / 5} \cdot r_{1}^{-1 / 5}
\end{aligned}
$$

衰 3.1 壁面变位

\begin{tabular}{|c|c|c|c|c|c|c|c|c|}
\hline 列 & 1 & 2 & 3 & 4 & 5 & 6 & 7 & 8 \\
\hline 1 & 0.002 & 0.005 & 0.027 & 0.074 & 0.097 & 0.076 & 0.072 & 0.075 \\
\hline 2 & 0.006 & 0.007 & 0.028 & 0.064 & 0.077 & 0.068 & 0.066 & 0.068 \\
\hline 3 & 0.011 & 0.025 & 0.029 & 0.059 & 0.065 & 0.064 & 0.061 & 0.066 \\
\hline 4 & 0.026 & 0.046 & 0.052 & 0.056 & 0.056 & 0.053 & 0.061 & 0.060 \\
\hline 5 & 0.028 & 0.050 & 0.051 & 0.053 & 0.052 & 0.052 & 0.054 & 0.058 \\
\hline 6 & 0.029 & 0.050 & 0.051 & 0.050 & 0.051 & 0.050 & 0.051 & 0.052 \\
\hline
\end{tabular}

ここに, $P$ は重鍾衝撃力, $y$ は貫入量, Wは重錘重量, $H$ は落下高, $\lambda$ はラーメの定数, $r_{1}$ は重錘 の換算半径である.

式(3.2)により実物実験の条件を用いて貫入量を求めた結果, $929 \mathrm{~mm}$ となり実験結果とほぼ同様の値 である.

これらのことから,ポケット式落石防護補強土擁壁に作用する衝撃力および貫入量は,「振動便覧の 推定式」により求められることがわかった.

\section{4. 简易設午法による照查}

\section{1 照查方法}

実物実験結果により得られた重鍾衝擊力から, 設計衝撃力を推定し, 補強土擁壁の内的安定の検討 により供試体の照査を試みた．補強土擁壁の検討としては補強領域を擬似擁壁と見なした外的安定の 検討も実施されるが，外的安定の検討は背面地盤からの作用土圧が支配的となり，落石衝撃力の影響 が小さいと考えられるため，照査を省略した。 


\section{2 設計条件}

図 4.1 に簡易計算概略図を示す。ポケット 式落石防護補強土擁壁の内的安定の検討は, 天端に設計衝撃力が上載荷重として作用した 補強土擁壁として行うものとする。

衝撃土圧の分散については, 敷砂に対する 重錘落下実験で 1:0.5 1:0.8 の範囲である と報告されており ${ }^{3)}$, 実物実験においても鈶 直土圧の計測結果により $1: 0.5$ 以上の分散が 確認されている。よって，衝撃土圧の分散は 無転圧層内を $1: 0.5$ で分散するものとする.

落石衝撃力は, 図 4.1 に示すように, 無転 圧層内を $1: 0.5$ で分散させ補強土壁の上面に 分布荷重として作用させた。

計算に用いる土質定数は，実物実験供試体より試料を 採取し, 室内試験により求めた. また, 補強材の強度は, 計算上は通常クリープを考慮した強度を使用するが, 実 験では供試体構築から実験実施までにあまり日数を置い ていないため，補強材のクリープによる影響は考虑しな

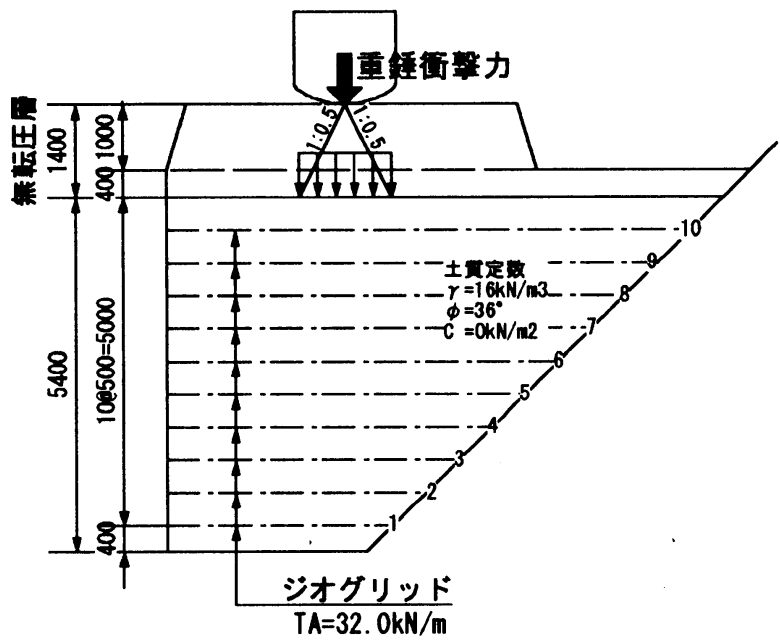

図 4.1 简易計算概略図 いこととし，引張強度を $32 \mathrm{kN} / \mathrm{m}$ とした．載荷する重鍾衝擊力は，実験時に計測された值とし, $2417 \mathrm{kN}$ とした。表 4.1 に計算条件の一覧表を示す.

重鍾衝撃力と衝撃土圧の合力については様々な研究例があるが 4),5),6)，今回は，ポケット式落石防 護補強土擁壁を構成する主材は土砂であり, 被衝突物の剛性が低いことから, 重鍾衝撃力と衝撃土圧 合力は等しいものとして設計を行うこととする.

\section{3 内的安定の検討}

実験において，ポケット式落石防護補強土擁壁は破壊にまで至らなかった，したがって，落石衝撃 力に対する安全率を 1.0 以上は有していると考えられる.また, 落石衝撃力は局部的な荷重であるが, 補強土擁壁に伝達した衝撃力は, 補強土擁壁内で分散する. したがって, 衝突時に安全率が 1.0 を超 える補強土擁壁の分担幅を試行錯誤的に求めた。ここで，荷重の分担幅とは，衝擊荷重に対して，補 強土擁壁が抵抗する延長を示す。

検討の結果，荷重の分担幅が $5.0 \mathrm{~m}$ で最小安全率が 1.030 となった. 図 4.2 に安全率が最小となる

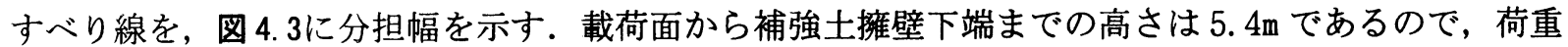
の分散勾配は約 $1: 0.7$ となり,衝撃土圧の分散勾配である $1: 0.5 \sim 1: 0.8$ の範囲には当てはまるものの, 通常の補強土の分散勾配は $1: 0.5$ とされており ${ }^{7)}$ ，それよりも大きい值となった。ここで, 分散勾配 は図 4.3 に示すように，分布荷重の端部と，分担幅端部における壁高の中心を結んだ勾配とした。 


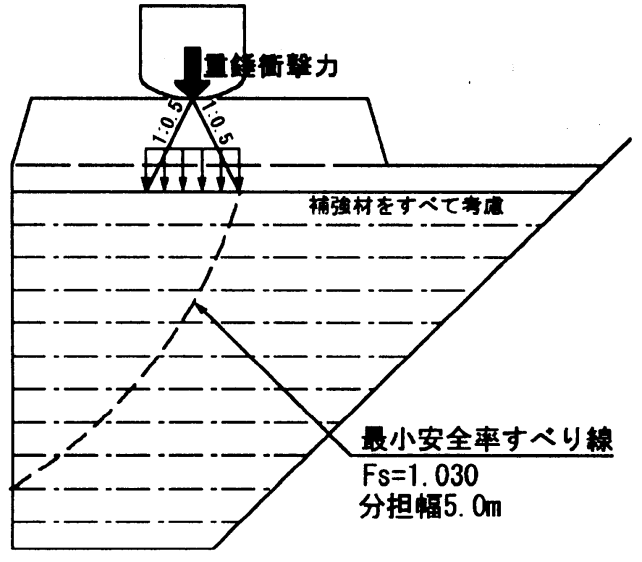

図 4.2 最小安全率すへりり線

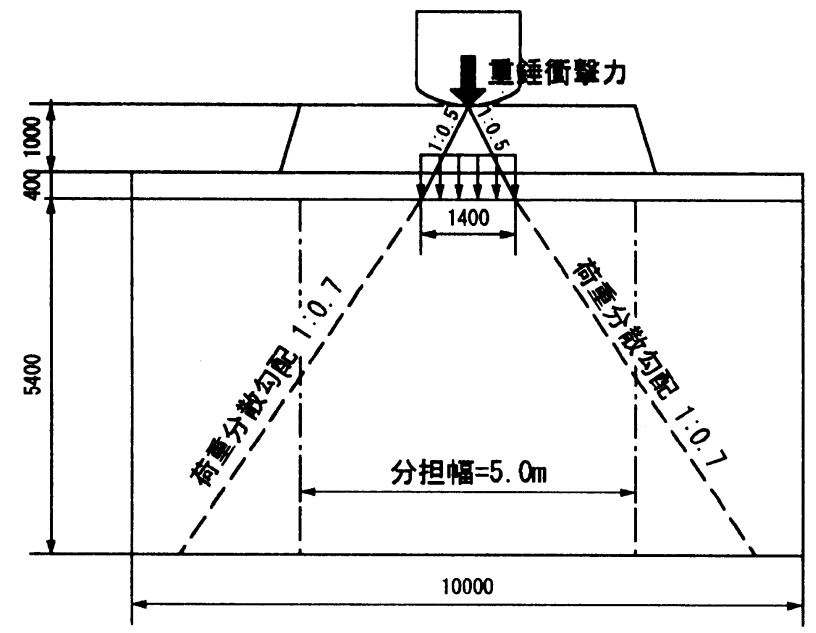

図 4.3 荷吾分担幅

衰 4.2 各ジオグリッドに作用する引張力

すべり線は荷重作用位置の端部か ら補強土擁壁下端より $1.0 \mathrm{~m}$ の位置 にかけて生じている，実験時の壁面 変位も,壁下端の約 $1.0 \mathrm{~m}$ の位置より 上方に向かって変位が増加して拈り， すべり線の位置は概ね妥当であると 思われる。

䒾 4.2 に各ジオグリッドの引張力 に対する照査結果を示す，照査の結

\begin{tabular}{|c|c|c|c|c|}
\hline 位直番号 & $\begin{array}{c}\text { 擁壁天端から } \\
\text { の距離 }(\mathrm{m})\end{array}$ & $\begin{array}{c}\text { 作用引張力 } \\
\mathrm{T}(\mathrm{kN} / \mathrm{m})\end{array}$ & $\begin{array}{c}\text { 許容引張力 } \\
\mathrm{T}_{\mathrm{A}}(\mathrm{kN} / \mathrm{m})\end{array}$ & 判定 \\
\hline 10 & 0.5 & 51.096 & 32 & $\times$ \\
\hline 9 & 1.0 & 28.222 & 32 & $\mathrm{O}$ \\
\hline 8 & 1.5 & 24.753 & 32 & 0 \\
\hline 7 & 2.0 & 22.609 & 32 & 0 \\
\hline 6 & 2.5 & 21.282 & 32 & $\mathrm{O}$ \\
\hline 5 & 3.0 & 20.492 & 32 & $\mathrm{O}$ \\
\hline 4 & 3.5 & 20.075 & 32 & $\mathrm{O}$ \\
\hline 3 & 4.0 & 19.928 & 32 & $\mathrm{O}$ \\
\hline 2 & 4.5 & 20.452 & 32 & $\mathrm{O}$ \\
\hline 1 & 5.0 & 27.326 & 32 & $\mathrm{O}$ \\
\hline
\end{tabular}

果, 最上段のジオグリッドのみ作用引張力がジオグリッドの引張強度を上回ったが, 2 段目以下のジ オグリッドに作用する引張力はジオグリッドの引張強度以下となった，実験時にも，最上段のジオグ リッドは破断しており, 実験結果と一致した。

\section{4 考察}

実験結果の再現計算として，重鍾衝擊力を静的な分布荷重として補強土擁壁天端に作用させ，内的 安定照査による検討を行った。照査の結果，ほぼ実験結果を再現することができた，計算上，最小安 全率が 1.0 を超える分散幅は $5.0 \mathrm{~m}$ となり，荷重分散勾配は約 $1: 0.7$ であった．また，計算上最上段の 補強材が破断する結果となり，実験結果をよく再現していると思われる。したがって，落石による衝 暂力が作用した場合の内的安定は，衝蒰力を静的な上載荷重に置き換えることで，通常行われている 補強土擁壁の安定照査法で評価が可能であると思われる。

ただし, 荷重の分散勾配については, 通常の補強土内の荷重分散幅である 1:0.5よりも大きい值と 
なった。このことは，簡易計算において壁面ブロックの影響を考虑していないため，計算上は実際の 分担幅よりも大きな值を示したものと考えられる．また，補強土擁壁内部の荷重分散勾配は 1:0.5 と されている ${ }^{7)}$.よって，設計計算を行う場合は安全側を考慮し，荷重の分散勾配は 1:0.5 に抑えた方 がよいと思われる。

重鍾衝撃力に関しては，実験状況の再現のため実験時に観測された値として計算を行ったが，この 場合の振動便覧における落石衝撃力の推定式のラーメ定数は $700 \mathrm{kN} / \mathrm{m}^{2}$ となる．しかしながら，前述し たように，通常衝撃力算出時の緩衝材のラーメ定数は一般的に $1000 \mathrm{kN} / \mathrm{m}^{2}$ 程度であるとされている. したがって，設計に用いる際の衝擊力は，安全側を考慮し，ラーメ定数を $1000 \mathrm{kN} / \mathrm{m}^{2}$ として算出した 方が良いと思われる。

5. まとめ

本研究では，補強土を用いたポケット式落石防護補強土擁壁の開発を目的として，モデル実験およ び実物実験を実施した。実験ではその構造特性と安全性を確認し，また，実験により得られた結果を もとに簡易設計法による照查を試みた。本研究により得られた結果をまとめると以下のようになる.

(1)擁壁体に補強材を設置することにより，鉛直荷重に対する安全性を高めることができる.

(2)実物実験により, 重量 $51.7 \mathrm{kN}$, 落下高 $20 \mathrm{~m}$ の条件においてポケット式落石防護補強土擁壁の安全 性を確認することができた。

(3)ポケット式落石防護補強土擁壁の天端に作用する重鍾衝擊力は振動便覧の推定式により推定する ことができる。

(4) ポケット式落石防護補強土擁壁天端の無転圧層への貫入量は振動便覧式により推定することがで きる。

(5)ポケット式落石防護補強土擁壁の簡易計算手法として, 天端に静的に置き換えた衝擊力を作用させ た補強土擁壁の内的安定の検討で, 概ね実験結果を再現する荷重の分担幅を確認することができた. したがって，この計算手法によりポケット式落石防護補強土擁壁の設計が可能である.

以上のことからポケット式落石防護補強土擁壁は, 道路際に平坦地がない場合の落石防護工として, 十分に適用可能であると考えられる.

しかし，実物実験において壁面ブロックのずれが確認されたことから, 壁面変位を抑えるための構 造や壁面にずれが生じた場合の補修方法等について今後検討を行う必要がある.また, 簡易計算手法 では，荷重の分散方向を直線的なものとしたが，ロックシェッドの設計においては，山側受台に作用 する背面落石による土圧は，ブシネスクの応力分布が用いられている．したがって，今後は，様々な 条件でモデル実験を行い, 衝撃荷重の分散方向のデータを蓄積していきたいと考えている．さらに, 実験を解析的に再現し, 内部応力の伝達・分散の挙動を把握することで荷重の分担幅や補強土擁壁の 変形挙動を確認し, 簡易計算手法を確立していきたいと考えている. 
1)小畑康隆, 㴊上正浩, 横田善弘, 野村利充, 吉田博 : ジオシンセティックスを用いた落石防護擁壁 の実物実験について，国際ジオシンセティックス学会日本支部論文集第 13 巻, pp.61-68, 1998.12. 2)小烟康隆, 㴥上正浩, 横田善弘, 久保哲也, 野村利充 : ジオシンセティックスを用いた落石防護擁 壁の動的応答解析, 国際ジオシンセティックス学会日本支部論文集第 14 巻, pp. 93-100, 1999. 12.

3) 米田義弘, 慗田修三, 古賀泰之, 松葉美晴, 佐藤彰 : 落石覆工に作用する落石衝撃力に関する重錘 落下実験, 第 2 回落石等による衝擊問題に関するシンポジウム論文集, pp. 161-166, 1993.6.

4) 金沢大学工学部土木工学科構造力学研究室: 防護覆い上への落石による衝撃力の推定に関する研究, 1984. 1.

5) 岸徳光, 中野修, 松岡健一, 西 弘明: 野外実験による敷砂の緩衝性能, 土木学会構造工学論文集, Vo1. 39A, pp. 1587-1597, 1993. 3.

6)㴊上正浩, 小畑康隆, 藤井智弘, 吉田 博 : 落石覆工の非線形性を考慮した落石衝撃力特性に関す る一考察，第 4 回構造物の衝撃問題に関するシンポジウム論文集, pp. 201-206, 1998.6.

7)財団法人 土木研究センター:ジオテキスタイルを用いた補強土の設計・施エマニュアル(改訂版), pp. 160-161, 2000. 2. 